\title{
EdD Students' Self-Efficacy and Interest in Conducting Research
}

\author{
Monica Reid Kerrigan \\ Rowan University, \\ Glassboro, NJ, USA
}

kerriganm@rowan.edu

\author{
Kimberly M. Hayes \\ Harlem Village Academies East \\ Middle School, \\ New York, NY, USA
}

kmwalker85@gmail.com

\begin{abstract}
Today's educational practitioners are expected to know how to gather, analyze, and report on data for accountability purposes and to use that information to improve student outcomes. However, there is little understanding of how to support practitioners' learning of and engagement with research and few studies on the research experiences of students enrolled in Doctorate of Education (EdD) programs. The success of students enrolled in Doctor of Philosophy $(\mathrm{PhD})$ programs in conducting research has been found to be related to students' self-efficacy and interest, but these concepts have not been explored with EdD students who are more likely to engage in applied research in their workplace than to create a research-focused career. This study sought to understand the self-efficacy and interest that EdD students enrolled in an Educational Leadership program have in research skills and tasks in order to improve research course offerings. Our findings with EdD students are consistent with existing research on $\mathrm{PhD}$ students regarding research selfefficacy but we did not observe significant changes in students' interest over time. We suggest avenues for future study in light of current accountability reporting requirements for practitioners.
\end{abstract}

Keywords: Doctoral students, practitioner-researcher, research skills, self-efficacy

\section{Introduction}

Calls for the reconceptualization, reboot, elimination, and other revisions to the American education doctorate (EdD) are plentiful (Deering, 1998; Levine, 2005; Shulman, Golde, Bueschel, \& Garabedian, 2006; Townsend \& Hall, 2002; Wergin, 2011). There is broad agreement that the EdD was originally developed to be a practitioner-oriented degree (Deering, 1998; Townsend \& Hall, 2002), in contrast to the research and scholar oriented $\mathrm{PhD}$, and that today's EdD degree suffers from questions of purpose, quality, and value. Universities have interpreted and imple-

Material published as part of this publication, either on-line or in print, is copyrighted by the Informing Science Institute. Permission to make digital or paper copy of part or all of these works for personal or classroom use is granted without fee provided that the copies are not made or distributed for profit or commercial advantage AND that copies 1) bear this notice in full and 2) give the full citation on the first page. It is permissible to abstract these works so long as credit is given. To copy in all other cases or to republish or to post on a server or to redistribute to lists requires specific permission and payment of a fee. Contact Publisher@InformingScience.org to request redistribution permission. mented the education doctorate in different ways; some programs focus on the professional experiences and needs of practitioners while others are akin to a traditional $\mathrm{PhD}$ (Courtenay, 1988). Considering these two approaches to doctoral studies provides an opportunity to explore the preparation of doctoral students for their future professional responsibilities. 
From kindergarten to university, today's teachers and educational administrators are expected to engage in an applied research process involving gathering, analyzing, and reporting on data for accountability purposes and to use those data to improve student outcomes. This process is different from "conventional" research (Riehl, Larson, Short, \& Reitzug, 2000) that is taught and conducted in traditional $\mathrm{PhD}$ programs. Unlike $\mathrm{PhD}$ programs, which expressly cultivate students' interest in research for the purpose of developing researchers - although most graduates are not employed as faculty - the EdD is expected to develop existing practitioners into practitionerresearchers who can develop, implement, evaluate, and improve programs in their workplace on the basis of empirical research. This distinction may be framed as a difference between conducting research about and within one's own institutional context versus developing a broader research agenda that is connected to the wider interests of the academic community; yet, we know little about educational practitioners' early engagement with research. Using data collected from an ongoing assessment of research courses in an EdD program, this article explores students' research self-efficacy - defined as the degree to which an individual believes he or she can successfully complete tasks - and interest in research-related tasks to understand the experiences of practitioners learning about research within a context of developing practitioner-researchers.

\section{Background}

This article draws upon data from an assessment of four required research courses in an Educational Leadership EdD program at a comprehensive university in the Northeastern United States. This program is a highly structured, cohort driven program that primarily attracts practitioners who are interested in a doctorate for personal reasons or to advance their career; few students enroll with the purpose of becoming researchers or scholars. The program educates practitionerresearchers, defined as "someone who is employed in a professional capacity but who, as part of their role, is expected to undertake research" (Fox, Martin, \& Green, 2007). Practitioner inquiry includes a variety of endeavors including "action research, teacher research, self-study, the scholarship of teaching, and using practice as a site for research" (Cochran-Smith \& Lytle, 2009, p. 39). To address the research component of this responsibility, the Educational Leadership program offers a four course research sequence - Action Research in Educational Leadership; Issues in Qualitative Analysis in Educational Research; Mixed Methods Research in Educational Leadership; and Dissertation Seminar II - which focuses on developing the dissertation research design. The research on which this article is based emerged from an effort to understand EdD students' experiences with research over time in their EdD program research courses and to explore connections between conventional research and the information gathering that practitioners do as part of data driven accountability efforts.

As a first step in understanding the research interests and self-efficacy of students enrolled in an Educational Leadership EdD program, this paper summarizes the current literature on the EdD program debate. We summarize the research on the conceptual differences between $\mathrm{PhD}$ and $\mathrm{EdD}$ programs in the United States in relation to the idea of developing researchers and discuss the educational challenges that result from these distinctions. Second, although empirical research on the research courses taken by EdD and PhD students is limited - Leech and Haug (2015) explore graduate research and statistics courses and Turner (2010) studied the process of teaching a graduate research course to teachers - relevant research on doctoral students as beginning researchers is discussed, with attention paid to studies that used the instruments used in this paper. Finally, we review the literature on research self-efficacy and interests, rooted in Bandura's $(1977,1986)$ notion of self-efficacy. Based on this existing literature, six hypotheses relating to the development of research self-efficacy and interest among students enrolled in an EdD program are then presented. 


\section{Developing Researchers in Education Schools}

A history of the EdD and its evolving purpose is beyond the scope of this article, but is available from Perry (2012). Although fundamental questions of how to teach research methods and what to teach is not limited to EdD programs (Page, 2001), becoming a researcher requires a significant shift in professional identity for EdD students who view themselves as accomplished practitioners (Taylor, 2007). As a result, existing research on what contributes to $\mathrm{PhD}$ students' research success and researcher identity may not apply.

Cultural and practical challenges to developing researchers exist in EdD programs. Tensions may arise due to the persistent cultural differences and worldviews that stem from the divergence of the practical experiences and professional accomplishments that educational leadership students bring with them to doctoral studies and the academic experiences and expectations of their faculty (Labaree, 2003). As Riehl, Larson, Short, and Reitzug (2000) suggest, practitioners and researchers "have inhabited largely different worlds within educational administration" (p. 398), which has led to a distinction that the authors characterize as conventional research versus practical research. The importance of this distinction is further heightened by the growing accountability demands placed on practitioners; EdD programs must prepare practitioners to conduct rigorous applied research that meets practitioners' needs.

However, even when diverging worldviews and cultures are addressed, there still remain practical challenges. For example, Bernauer, Semich, Klentzin, and Holdan (2013) address the difficulties of teaching research skills to students in accelerated and highly structured doctoral programs, in which students have little time to engage with various methodologies that they might employ in their dissertation or in their field. Gardner and Gopaul (2012) identify challenges associated with being a part-time doctoral student including balancing their studies, work responsibilities, and personal commitments.

\section{Doctoral Students as Beginning Researchers}

The challenges of educating educational practitioners as researchers notwithstanding, there is also a parallel process of doctoral students as beginning researchers that must also be considered. Leech (2012) proposed a new model of educating PhD students to support their development into successful researchers drawing upon Bozeman, Dietz, and Gaughan's (2001) theory of scientific and technical human capital, Levine's (2005) study of education schools, and Lovitts' (2005) model of environmental factors and individual resources that support the production of research.

One of the ways that traditional $\mathrm{PhD}$ programs develop beginning students' identity as researchers is through mentoring. In one study, Baker and Pifer (2014) explore the identity development as doctoral students transition from student to scholar. They label stage 3 of the doctoral student experience - the dissertation - as knowledge enactment, and specifically explore the emergence of the independent scholar identity, simultaneous with the ongoing student identity. This identity develops through a process of legitimization in the academic community and enactment of scholar behaviors and practices concurrent with ongoing mentoring. However, mentoring practitionerresearchers (Cochran-Smith \& Lytle, 2009) is particularly complex in EdD programs for a few reasons: a) faculty in such programs are more likely to hold conventional conceptions of a researcher identity rather than practitioner-oriented conceptions; b) students in such programs are looking not for a new identity, e.g., from professional to educational researcher, but rather they are looking to further develop their existing identity as an experienced professional. In addition, as is evident from the literature discussed earlier, research on $\mathrm{PhD}$ students may not be applicable; for example, relying on mentors who are not practitioner-researchers to mentor practitioners may be less effective. Furthermore, models such as Baker and Pifer's (2014) stage model have limited applicability given that their components are particular to full-time PhD students (e.g., Baker and Pifer's fourth stage refers to the academic job search). 


\section{Research Self-Efficacy and Interests}

Bandura (1986) explored the relationship between confidence about one's own abilities and behavioral changes in self-efficacy theory. The perceived level of confidence one possesses about one's own capabilities in a task can affect future behavioral settings, i.e., how much effort individuals expend and their level of persistence in a difficult task, which can, in turn, affect outcomes. Individuals learn about their capabilities through four possible experiences: actual performances, vicarious experiences, forms of social persuasion, and physiological indexes. Effects of self-efficacy include motivation, learning, self-regulation, and achievement (Schunk \& Pajares, 2002). These perceived capabilities are not to be confused with other influences on behavior, such as self-esteem, self-concept, or self-confidence. The importance of self-efficacy theory is in its effects: specifically, the likelihood that one will engage in activities that are at a certain level of difficulty and whether or not someone will choose to persist through adversity and give greater effort to achieving that goal (Holden, 1992)

Bandura's $(1977,1986)$ work suggests that, provided the domains are similar, self-efficacy beliefs about one task can transfer across different domains; these findings supported the developed of domain specific scales including that of the Research Self-Efficacy Scale (Bieschke, Bishop, \& Garcia, 1996; Holden, Barker, Meenaghan, \& Rosenberg, 1999). Researchers have used the concept of general self-efficacy and applied it to a wide range of situations from assertiveness (Lee, $1982,1984)$ to athletic performance (Lee, 1982). These studies suggest that self-efficacy and behavior have a positive relationship and display a cyclical pattern in which increases in selfefficacy result in persistence in the desired behavior that in turn reinforces self-efficacy.

Numerous studies in social work (see Holden, 1992), counseling and counseling psychology (see Lambie \& Vaccaro, 2011), and psychology (see Forester, Kahn, \& Hesson-McInnis, 2004) have explored the relationship between self-efficacy in research and interest in research among graduate students, particularly $\mathrm{PhD}$ students. Other studies have examined graduate programs more generally (Chesnut, Siwatu, Young, \& Tong, 2015; Unrau \& Beck, 2004). Since empirical research is generally new to graduate students and is often perceived as difficult (Wao et al., 2009), the willingness to engage in difficult activities and to persist with those activities is important to educating doctoral students. However, given the aforementioned discussion of differences between PhD and EdD students, it remains to be seen whether the same relationship between selfefficacy and research interest exists for EdD students.

\section{Specific Hypotheses on Research Self-Efficacy and Interests}

Since Bandura (1977, 1986), Schunk and Pajares (2002), and others have noted that individuals may learn about their capabilities through actual performances, vicarious experiences, and forms of social persuasion, all of which occur in the context of research courses, EdD students' research self-efficacy should increase as they take more research courses. Thus, we proposed the following hypothesis:

Hypothesis 1: EdD students' research self-efficacy increases with each research course that they complete.

Practitioners may not conceive of research as relating to their practice; therefore, exposure to research through coursework is instrumental for informing and shaping their understanding of what research is and how it relates to practitioner inquiry. This understanding is necessary to develop interest in research.

Hypothesis 2: EdD students' research interest increases with each research course that they complete. 
The existing literature consistently finds a positive relationship between research self-efficacy and interest among PhD students, thus we proposed that this relationship would also hold true for EdD students.

Hypothesis 3: A positive relationship exists between EdD students' interest in research and their research self-efficacy.

There is a general consensus in the research that there is no difference between male and female $\mathrm{PhD}$ students in research self-efficacy or interest in research scores. Since the education field is dominated by women, we looked to confirm that finding in our own research on EdD students.

Hypothesis 4: EdD students' research self-efficacy and interest do not differ by sex.

We also suggest that these ideas of research self-efficacy and interest do not sufficiently account for EdD students' development of a practitioners-researcher identity. Developing a researcher identity is a complex process in any doctoral program (Murakami-Ramalho, Piert, \& Militello, 2008; Murakami-Ramalho, Militello, \& Piert, 2013; Taylor, 2007). Thus we also wanted to explore possible relationships between research self-efficacy, interest, and prior research experience that practitioner-researchers may have had in their workplace before beginning the EdD program.

Hypothesis 5: EdD students' research self-efficacy differs by prior research experience

Hypothesis 6: EdD students' interest in research differs by prior research experience.

\section{Methods}

The purpose of this research was to explore the development of and relationship between EdD students' interest in conducting research and their self-efficacy relating to research tasks over four research courses using previously collected assessment data from a research sequence in an Educational Leadership doctoral program. This research was approved by the IRB board at the research site. A questionnaire was developed to collect data including demographic information and responses to two validated instruments: the Research Self-Efficacy Scale (Holden et al., 2007) and the Interest in Research Questionnaire (Bieschke \& Bishop, 1994). These data enabled an analysis of students' interest and confidence in carrying out discrete research tasks at more than one point in time.

\section{Procedure}

Over a two-year period, faculty teaching research methods courses in the EdD program were asked to administer the questionnaire at the beginning of the term. The questionnaire was available in paper format and online. Not every faculty member administered the questionnaire but when it was administered, it was administered at the beginning of the term. This timing was deliberate to minimize concerns with social desirability (Fowler, 2002). The intent was to ensure that students understood that the questionnaire was not measuring their experiences or performance in the current course and, therefore, would have no impact on their grade or their instructor's perception of them.

To ensure anonymity, we used Holden et al.'s (1999) approach to develop a personal identification number (PIN) that would be known only to the students. This unique PIN should have enabled completed questionnaires to remain anonymous while still enabling us to track individuals over time to see if there are changes in students' confidence and interest in research as they progress through the doctoral program. However, upon reviewing the data, we found that some students were unable to reconstruct the same PIN, which prohibited our ability to track all of the students over time. 


\section{Instruments}

The first part of the questionnaire included instructions for generating the anonymous PIN. Students were also asked for basic background information including when they began the program, their previous experience with empirical research, and the number of research courses they completed prior to enrolling in the doctoral program. The rest of the questionnaire included the two instruments discussed below.

\section{The research self-efficacy scale}

The Research Self-Efficacy Scale (RSES) was developed by Holden et al. (2007) to capture students' confidence in carrying out research tasks, such as conducting a literature review, formulating a research question, designing a research study, and presenting research. To measure their level of confidence, students are asked to respond using a 100-point scale with 0 corresponding to "cannot do at all" 50 corresponding to "moderately certain can do" and 100 corresponding to "certain can do." This scale was validated by Bieschke et al. (1996) and found to have four main factors representing the stages of the research process: a) Conceptualization; b) Early Tasks; c) Implementation; and d) Presenting Results. These four factors accounted for $57 \%$ of the variance (Bieschke et al., 1996).

\section{Interest in research questionnaire}

The Interest in Research Questionnaire (IRQ) was developed by Bieshke and Bishop (1994) and asks students to use a 5-point scale ( 1 is not interested, 3 is indifferent, and 5 is very interested) to indicate the degree of interest they have in specific research related activities. These activities include reading a journal article, conducting a literature review, conducting research where they work, and analyzing data. The scale was validated by Bieshke and Bishop (1994).

\section{Sample and Participants}

The data include questionnaire responses from EdD students enrolled in a highly structured cohort-based Educational Leadership program; the data were collected over a two year period. Participants were not sampled; all students who were enrolled in the courses where the questionnaires were administered were included, but, as is evident by Table 1, the questionnaire was not administered to every class.

Table 1. Number of students and returned questionnaires by cohort and course

$\begin{array}{ccccc}\text { Research } & \text { Research } & \text { Research } & \text { Research } & \text { Total number of } \\ \text { course } 1 & \text { course } 2 & \text { course } 3 & \text { course } 4 & \text { questionnaires }\end{array}$

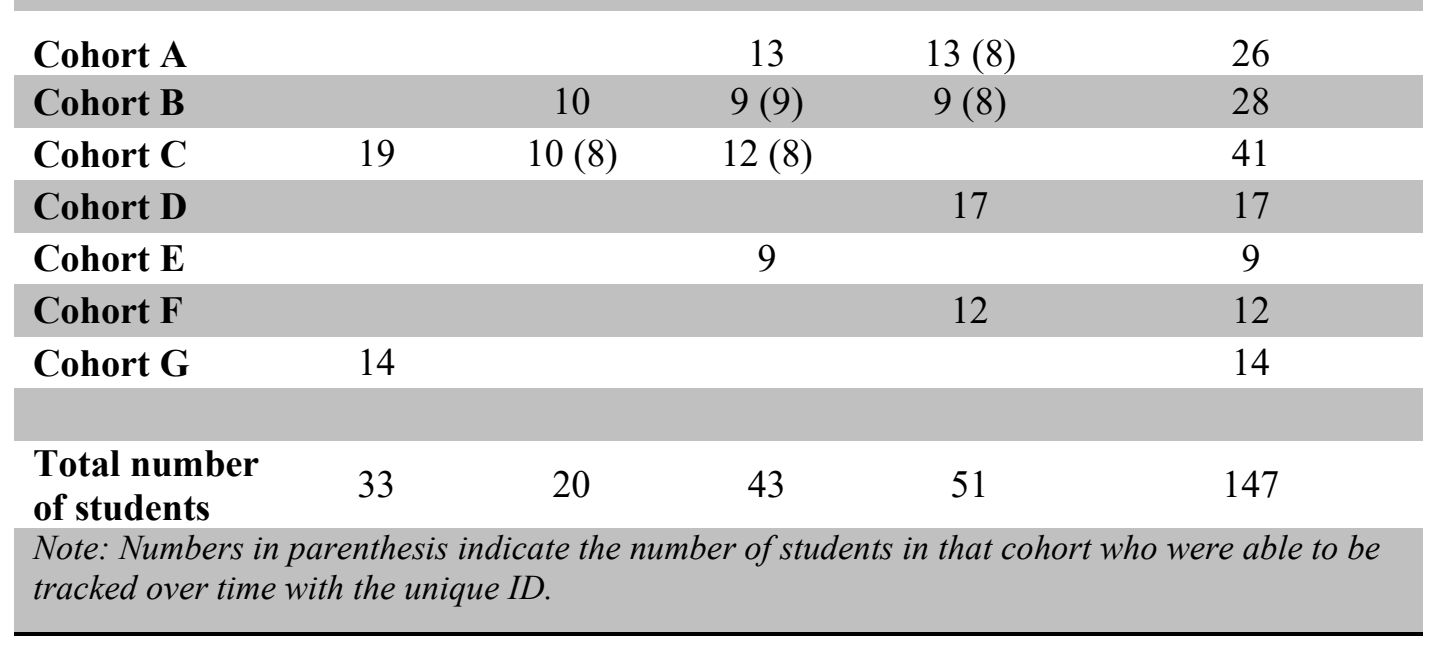


The completed questionnaires included data from seven different cohorts. Cohort A completed the questionnaire at two time points: at the start of the third research course and at the start of the fourth research course. Cohorts $\mathrm{B}$ and $\mathrm{C}$ completed the questionnaire at three time points. There were initially 42 students across these three cohorts, but due to attrition and difficulties with the PIN, we ended up with 25 unique students who completed a questionnaire at least twice. The remaining cohorts, cohorts D, E, F, and G completed the questionnaire only once; this resulted in another 52 unique students. In sum, for four cohorts we have data from one point in time and for three other cohorts we have data at multiple points in time (see Table 1) resulting in 147 surveys and 94 unique students.

\section{Data Analysis}

Before beginning data analysis we screened the data for missing data and errors. Of the 147 returned surveys, all 147 included at least basic demographic information and information about prior research and work experience. All but one questionnaire included a fully completed selfefficacy section, and 142 included a fully completed interest questionnaire.

The data were analyzed using Stata 11.0. Preliminary analysis confirmed that our data were not normally distributed, thus the data were analyzed using non-parametric tests. This approach is consistent with that of Holden et al. (1999), whose data were also not normally distributed. Using only those records for which we had more than one point in time, a Wilcoxon matched-pairs signed-ranks test was used to determine if statistically significant differences exist in students' research self-efficacy and interest in research at different points in time in the research sequence. Comparisons were made between the data collected at the start of research courses two and three, and between research courses three and four. Hypotheses 1 and 2 guided this analysis.

To examine differences in research self-efficacy and interest based on prior research experience and sex, a Mann-Whitney ranksum was run separately for each group, to ensure independence. Hypotheses 4, 5, and 6 guided this analysis. Finally, guided by Hypothesis 3, a Spearman rank order correlation was run on the total scores of research self-efficacy and research interest for this group of students.

\section{Findings}

Demographics varied among the seven cohorts (see Table 2), but overall the participants were $60 \%$ female and $33 \%$ male; some participants did not indicate their sex. Survey participants varied in their experiences with research with $60 \%$ reporting empirical research experience in graduate school prior to the doctoral program but only $19 \%$ had conducted research in their workplace (see Table 2). Across all the participants, a little more than half of the respondents reported taking between 1 and 3 research courses prior to beginning the doctoral program.

\section{Hypothesis 1: EdD students' research self-efficacy will increase with each research course that} they complete.

The data suggest that EdD students' research self-efficacy increased with each research course they completed. Based on an examination of students for whom we had data at the start of research courses 2 and the research courses 3, students self-efficacy scores increased between the two courses (see Table 3). The differences ranged between 5.4 points to 18.6 points. A Wilcoxon Signed-Ranks Test indicated that self-efficacy scores at the start of research course 3 were significantly higher than at the start of research course $2(\mathrm{z}=-2.796, \mathrm{p}=0.0052)$.

Recalling that the self-efficacy scale was broken down into four factors - Early Tasks, Conceptualization, Implementation, and Presenting the Results - the data suggest that students increased their self-efficacy across all four areas between the start of the second research course and the 
start of the third research course. Early Task scores and Conceptualization ranks were significantly higher at the start of the third research course than at the start of the second research course (Early Task: $\mathrm{z}=-2.337, \mathrm{p}=0.0194$; Conceptualization: $\mathrm{z}=-2.871, \mathrm{p}=0.0041$ ). Self-efficacy in presenting the results of research also increased $(\mathrm{z}=-2.428, \mathrm{p}=0.0152)$. The only area in which we did not observe an increase in rank between the second and third research courses was in implementation (Implementation: $\mathrm{z}=-1.289, \mathrm{p}=0.1972$ ).

\begin{tabular}{lccccccc}
\hline \multicolumn{7}{c}{ Table 2. Descriptive statistics of participants } \\
\hline & Cohort & Cohort & Cohort & Cohort & Cohort & Cohort & Cohort \\
A & B & C & D & E & F & G \\
& $(n=13)$ & $(\mathrm{n}=10)$ & $(\mathrm{n}=19)$ & $(\mathrm{n}=16)$ & $(\mathrm{n}=9)$ & $(\mathrm{n}=12)$ & $(\mathrm{n}=14)$ \\
Female & $7(54 \%)$ & $7(70 \%)$ & $13(68 \%)$ & $11(69 \%)$ & $(6) 67 \%$ & $6(50 \%)$ & $6(43 \%)$ \\
Male & $6(46 \%)$ & $3(30 \%)$ & $6(32 \%)$ & $3(19 \%)$ & $3(33 \%)$ & $6(50 \%)$ & $4(29 \%)$
\end{tabular}

Percentage of students with prior research experience in graduate school
\begin{tabular}{|lccccccc|} 
Yes & $6(46 \%)$ & $4(40 \%)$ & $12(63 \%)$ & $13(81 \%)$ & $6(67 \%)$ & $7(58 \%)$ & $8(57 \%)$ \\
\hline No & $7(54 \%)$ & $6(60 \%)$ & $7(37 \%)$ & $3(19 \%)$ & $3(33 \%)$ & $5(42 \%)$ & $6(43 \%)$ \\
\hline
\end{tabular}

Percentage of respondents with workplace experience with research
\begin{tabular}{|lccccccc|} 
Yes & $2(15 \%)$ & $2(20 \%)$ & $3(16 \%)$ & $1(6 \%)$ & $1(11 \%)$ & $4(33 \%)$ & $1(7 \%)$ \\
\hline No & $11(85 \%)$ & $8(80 \%)$ & $16(84 \%)$ & $15(94 \%)$ & $8(89 \%)$ & $8(67 \%)$ & $13(93 \%)$ \\
\hline
\end{tabular}

\begin{tabular}{|c|c|c|c|c|c|c|c|}
\hline \multicolumn{8}{|c|}{ Number of research courses taken prior to the EdD program } \\
\hline None & $4(31 \%)$ & $5(50 \%)$ & $4(21 \%)$ & $4(25 \%)$ & $4(44 \%)$ & $4(33 \%)$ & $8(57 \%)$ \\
\hline $1-3$ & $9(69 \%)$ & $4(40 \%)$ & $15(79 \%)$ & $12(75 \%)$ & $4(44 \%)$ & $8(67 \%)$ & $5(36 \%)$ \\
\hline $4-6$ & $0(0 \%)$ & $0(0 \%)$ & $0(0 \%)$ & $0(0 \%)$ & $1(11 \%)$ & $0(0 \%)$ & $1(7 \%)$ \\
\hline $7+$ & $0(0 \%)$ & $1(10 \%)$ & $0(0 \%)$ & $0(0 \%)$ & $0(0 \%)$ & $0(0 \%)$ & $0(0 \%)$ \\
\hline
\end{tabular}

Examining development between research courses three and four presented a different picture (see Table 3). Although a Wilcoxon Signed-Ranks Test indicated that overall self-efficacy rank were significantly higher at the start of research course four than at the start of research course three $(\mathrm{z}=-2.148, \mathrm{p}=0.0317)$ we observed a different pattern among the subscales. There was no increase in the Early Tasks $(\mathrm{z}=-0.027, \mathrm{p}=0.9787)$ or Conceptualization $(\mathrm{z}=-0.856, \mathrm{p}=0.3918)$. Scores for Implementation did indicate a statistically significant increase between the two courses $(\mathrm{z}=-1.994, \mathrm{p}=0.0461)$ and in Presenting the Results $(\mathrm{z}=-2.428, \mathrm{p}=0.0152)$.

In sum, students' self-efficacy increased from research courses two to course three, and from research courses three to course four across some, but not all research tasks.

Hypothesis 2: EdD students' research interest will increase with each research course that they complete.

We found that EdD students' research interest did not increase between the start of the second course and the start of the third course or between the start of the third course and the start of the fourth course (see Table 4). A Wilcoxon signed-rank test determined that there were no statistically significant differences in research interest level between the start of the second and third research courses $(\mathrm{z}=-1.446, \mathrm{p}=0.1482)$ or between the start of the third and fourth research courses $(z=-0.648, p=0.5172)$. Thus, there was no support for this hypothesis that interest increased with more exposure to and experience with research. 


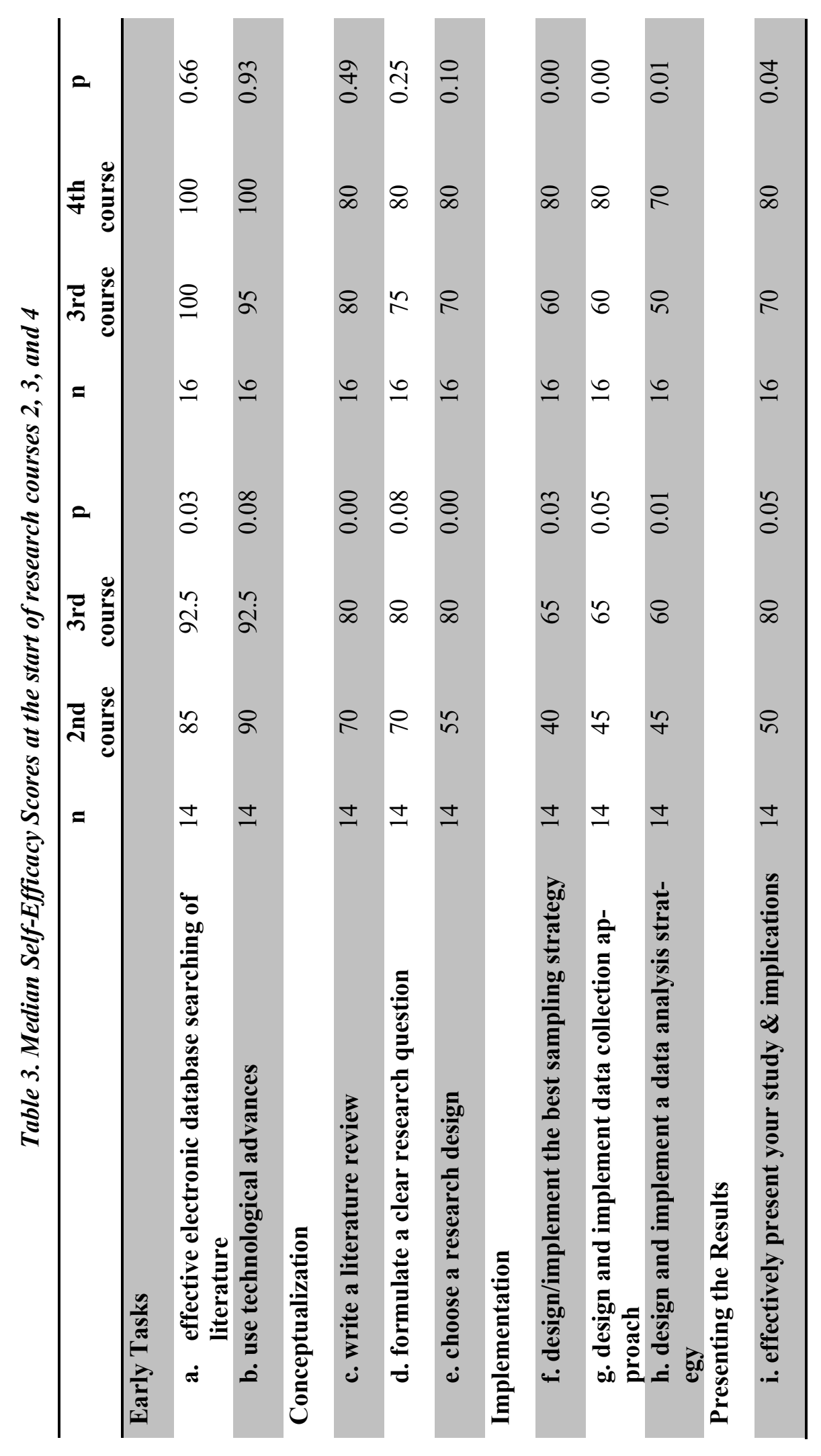




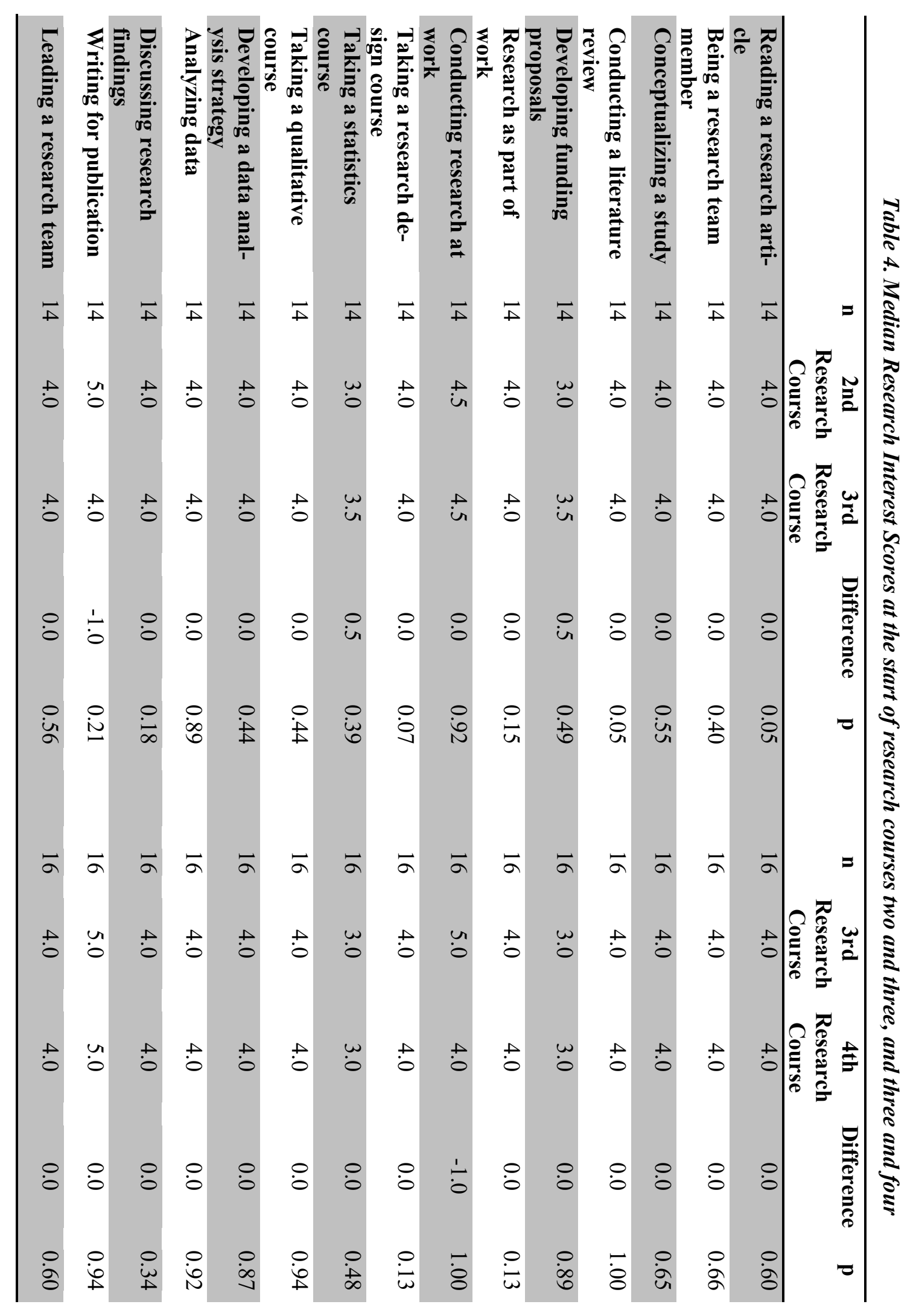


Hypothesis 3: There is a positive relationship between EdD students' interest in research and their research self-efficacy.

The data do not suggest the existence of a positive relationship between EdD students' interest in research and their research self-efficacy; there was no support for this hypothesis. We ran a Spearman rank order correlation on the total scores of research self-efficacy and research interest on the students at the start of each research course. Although the items within each instrument (i.e., research confidence and research interest) were at least moderately correlated with each other (rho $>0.5)$, the Spearman correlation between the total scores of research self-efficacy and research interest at the start of each of the four courses was very small and generally not statistically significant $(0.1<$ rho $<0.33)$.

Hypothesis 4: EdD students' research self-efficacy and research interest will not differ by sex.

The data support the hypothesis that EdD students' research self-efficacy and research interest did not differ by sex. We ran four separate Mann-Whitney ranksum tests, one for each course, and found no statistically significant differences in research self-efficacy by sex (see Table 5). There were no substantive or statistically significant differences in research self-efficacy by sex. At the start of the each research course, a Mann-Whitney ranksum test revealed no significant differences in the research interest of males and females (see Table 6).

Table 5. Research self-efficacy by course and sex

\begin{tabular}{lcccccc}
\hline & \multicolumn{1}{c}{ Males } & \multicolumn{3}{c}{ Females } & & \\
\hline & $\mathrm{n}$ & Median & $\mathrm{n}$ & Median & $\mathrm{z}$ & $\mathrm{p}$ \\
Start of course 1 & 10 & 600 & 19 & 560 & 0.781 & 0.435 \\
Start of course 2 & 6 & 625 & 12 & 460 & -1.501 & 0.133 \\
Start of course 3 & 19 & 660 & 24 & 650 & 0.404 & 0.686 \\
Start of course 4 & 16 & 615 & 31 & 690 & 1.584 & 0.113 \\
\hline
\end{tabular}

Table 6. Research interest by course and sex

\begin{tabular}{lcccccc}
\hline & \multicolumn{2}{c}{ Males } & \multicolumn{7}{c}{ Females } \\
\hline & $\mathrm{n}$ & Median & $\mathrm{n}$ & Median & $\mathrm{z}$ & $\mathrm{p}$ \\
Start of course 1 & 10 & 61.0 & 19 & 56.0 & -0.023 & 0.982 \\
Start of course 2 & 6 & 53.5 & 12 & 57.0 & -1.501 & 0.133 \\
Start of course 3 & 19 & 57.5 & 24 & 61.5 & 1.432 & 0.152 \\
Start of course 4 & 16 & 48.5 & 31 & 56.0 & 1.563 & 0.118 \\
\hline
\end{tabular}

\section{Hypothesis 5: EdD students' research self-efficacy will differ by prior research experience}

EdD students' research self-efficacy did not differ by prior research experience in this study. We analyzed total self-efficacy at the start of each course separately and compared a) students who had prior workplace research experience with those who did not and b) students who had prior graduate research experience with those who did not; we found that in either scenario, prior research experience did not matter. There were no statistically significant differences $(\mathrm{p}>0.113)$ between the groups at any of the four points in time. We also examined differences by selfefficacy sub-scale - Early Tasks, Conceptualization, Implementation, and Presenting the Results - and still found no statistically significant differences in research self-efficacy between those who had prior research experience and those who did not. 
Hypothesis 6: Students' interest in research will differ by prior research experience.

Students' interest in research did not differ by prior research experience. Total interest ranks at the start of each of the four research courses did not differ between those who had prior research experience, whether through work or through graduate work, and those who did not.

\section{Discussion}

This paper presents preliminary findings on the influences on research self-efficacy and interest among EdD students enrolled in an Educational Leadership doctoral program and also explores the relationship between self-efficacy and interest among EdD students. Drawing upon prior research on $\mathrm{PhD}$ students, we explored these constructs and the sub-items that relate to these constructs to develop six hypotheses. As presented in the findings section, the data supported two of the six hypotheses, suggesting that more research is needed to understand EdD students' engagement with research; the existing research on $\mathrm{PhD}$ students is not sufficient.

Initial analyses that explored the average overall research self-efficacy of students supported the hypothesis that students' research self-efficacy increased between research course 2 and 3 and between research course 3 and 4 but not across all subscales. These findings make sense once we review the syllabi of courses two, three, and four. Of particular note is a) the intensive review of all research tasks in course 2 and the fieldwork requirement in courses two and three; in other words, it is only at the start of courses three and four that students have completed an empirical research study involving fieldwork. Thus, finding an increase in research self-efficacy across all tasks makes sense when comparing students' at the start of the second course and the start of the third course. Similarly, the third research course does not emphasize Early Tasks at all; however, it does address Conceptualization, Implementation, and Presenting the Results so an increase in research self-efficacy in the latter two courses makes sense while the absence of an increase in Conceptualization does not. Further research is warranted to make sense of this finding.

The absence of increased interest in research between courses was surprising; we had hypothesized that with greater familiarity and self-efficacy, interest would also increase. Indeed, prior research (Holden, 1992; Lambie \& Vaccaro, 2011) suggests that students tend to be more interested in tasks they are good at, which we thought would also apply to tasks in which they report feeling more efficacious. However, this was not the case among the students in this research. There was very little change in interest from one course to the next. This finding may have significant implications for EdD programs; generating interest in research tasks is important given the increasing expectations for conducting research as part of educators' work responsibilities. A program that is geared to developing practitioner-researchers must be more attentive to cultivating research interest among practitioners.

Prior research has found that interest and self-efficacy are positively related (Lambie \& Vaccaro, 2011; Vaccaro, 2009), however our research did not support this hypothesis. The absence of a relationship may be attributed to the absence of variation on the interest variables, i.e., students' interest remained constant across the time. Research on interest suggests that interest is related to identity (Graham-Matheson, 2012) and, thus, further investigation is needed to explore the relationship between practitioner's identity and their understanding of the role of research in that identity. Earlier research (Zambo, Zambo, Buss, Perry, \& Williams, 2014) has found that students in EdD programs do learn to become scholar-practitioners although the emergence of that identity has not been closely examined. It is also worth noting that research on scientists' interests has found that interest remained stable over a 10-year period (Horn et al., 2007); understanding how students' interest in research changes, or not, over time may be worth exploring further.

Although our research on EdD students did not support existing findings on the relationship between interest and self-efficacy, the data does corroborate the absence of a difference in self- 
efficacy and interest by sex. Given the prevalence of women in the field of education, we did not expect to find a difference between males and females.

Finally, the last hypothesis proposed that students' interest in research would differ by prior experience. This hypothesis suggested that students who had experience with research, either in graduate school or in their workplace, would have a greater interest in conducting research. Although prior research has examined the effect of research courses and career aspirations on interest (Vaccaro, 2009), the relationship between prior experience and interest has not been explored. Our research found no evidence of a relationship between students' interest in research and prior research experience, whether at work or in graduate school. Further research is needed to understand how experiences affect and perhaps condition later interest. This may have implications for the literature on scholarly productivity.

\section{Limitations}

This article used data drawn from a non-representative sample of students enrolled in an EdD program in educational leadership and, thus, makes no assertions regarding the generalizability of its findings. However, the standard of transferability (Lincoln \& Guba, 1985) is used and the researchers hope that other programs will seek to test these six hypotheses with their population of EdD students in order to contribute to the literature on EdD students. At a minimum, the data suggest that there may be real differences in the experiences and interests of EdD students as compared with $\mathrm{PhD}$ students.

The findings of this study are also impacted by the fact that some students were not surveyed at the start of each course and that only a subset of students developed a PIN that they remembered and that enabled us to track them over time. Future research will seek to resolve this problem and establish a more consistent and reliable longitudinal dataset of students over time so that the entire dataset may be treated not just as a cross-sectional dataset but also longitudinally.

\section{Conclusion}

This study sought to understand what influences the confidence and interest in research among EdD students in order to improve course offerings and better prepare practitioners for the research that they will inevitably engage in as part of the work responsibilities given current accountability expectations. In sum, we found evidence of increasing research self-efficacy over time in certain research related tasks; no relationship between interest and self-efficacy; and no relationship between prior research experiences and EdD students' interest in research. Within the context of developing practitioner-researchers, since these findings suggest that coursework contributes to self-efficacy, we propose that EdD programs consider developing their research course offerings to expose students more extensively to research and how to apply research skills to data-driven accountability expectations that occur in the workplace. This is in contrast to a perception among practitioners and practitioners-turned-faculty who may believe that practitioner oriented doctoral programs need less research coursework and experience than conventional doctoral programs. Although all doctoral programs should provide a solid foundation in research - a universal process regardless of the application or context - the purpose for which research is undertaken, the setting of the research, and the models faculty use to illustrate research to students do differ for $\mathrm{PhD}$ and EdD students. We share the outcomes of this study to provide information that might aid other EdD programs in their program development. Research on practitioners' research skills, confidence, and interest may contribute to the reconceptualization of the EdD, as suggested by Townsend and Hall (2002) and also to the redesign of programs specifically to address the need for rigorous assessment and evaluation practices within schools and universities. Improving practitioners' understanding of and ability to carry out research is critical in the current accountability climate. 


\section{References}

Baker, V. L., \& Pifer, M. J. (2014). Preparing for practice: Parallel processes of identity development in stage 3 of doctoral education. International Journal of Doctoral Studies, 9, 137-154. Retrieved from http://ijds.org/Volume9/IJDSv9p137-154Baker0623.pdf

Bandura, A. (1977). Self-efficacy: Toward a unifying theory of behavioral change. Psychology Review, 84, 191-215.

Bandura, A. (1986). Social foundations of thought and action: A social cognitive theory. Englewood Cliffs, NJ: Prentice Hall.

Bernauer, J. A., Semich, G., Klentzin, J. C., \& Holdan, E. G. (2013). Themes of tension surrounding research methodologies education in an accelerated, cohort-based doctoral program. International Journal of Doctoral Studies, 8, 173-193. Retrieved from http://ijds.org/Volume8/IJDSv8p173193Bernauer0397.pdf

Bieschke, K. J., \& Bishop, R. M. (1994). Interest in research questionnaire. Unpublished scale, Pennsylvania State University, State College.

Bieschke, K. J., Bishop, R. M., \& Garcia, V. L. (1996). The utility of the research self-efficacy scale. Journal of Career Assessment, 4(1), 59-75. Retrieved from http://doi.org/10.1177/106907279600400104

Bozeman, B., Dietz, J. S., \& Gaughan, M. (2001). Theory of scientific and technical human capital. International Journal of Technology Management, 22(7), 716-740.

Chesnut, S. R., Siwatu, K. O., Young, H. A., \& Tong, Y. (2015). Examining the relationship between the research training environment, course experiences, and graduate students' research self-efficacy beliefs. International Journal of Doctoral Studies, 10, 399-418. Retrieved from http://ijds.org/Volume10/IJDSv10p399-418Chesnut0914.pdf

Cochran-Smith, M., \& Lytle, S. L. (2009). Inquiry as stance: Practitioner research for the next generation. New York, NY: Teachers College Press.

Courtenay, B. C. (1988). Eliminating the confusion over the EdD and $\mathrm{PhD}$ in colleges and schools of education. Innovative Higher Education, 13(1), 11-20. Retrieved from http://doi.org/10.1007/BF00898127

Deering, T. E. (1998). Eliminating the Doctor of Education degree: It's the right thing to do. The Educational Forum, 62(3), 243-248. Retrieved from http://doi.org/10.1080/00131729808984350

Forester, M., Kahn, J. H., \& Hesson-McInnis, M. S. (2004). Factor structures of three measures of research self-efficacy. Journal of Career Assessment, 12(1), 3-16. Retrieved from http://doi.org/10.1177/1069072703257719

Fowler, F. J. (2002). Survey reasearch methods. Thousand Oaks, CA.: Sage Publications.

Fox, M., Martin, P., \& Green, G. (2007). Doing practitioner research. Thousand Oaks, CA.: Sage Publications.

Gardner, S. K., \& Gopaul, B. (2012). The part-time doctoral student experience. International Journal of Doctoral Studies, 7, 63-78. Retrieved from http://ijds.org/Volume7/IJDSv7p063-078Gardner352.pdf

Graham-Matheson, L. (2012). Who do you think you are? Developing your identity as a researcher. The Guardian: Higher Education Network.

Holden, G. (1992). The relationship of self-efficacy appraisals to subsequent health related outcomes. Social Work in Health Care, 16(1), 53-93. 
Holden, G., Barker, K., Meenaghan, T., \& Rosenberg, G. (1999). Research self-efficacy: A new possibility for educational outcomes assessment. Journal of Social Work Education, 35(3), 463-476. Retrieved from http://libpublic3.library.isu.edu/login?url=http://search.ebscohost.com/login.aspx?direct=true \&db=ehh $\& \mathrm{AN}=15786193 \&$ site $=$ ehost-live

Horn, R. A., McGowan, M. R., Mitchell, D. R., Mellott, R. N., Lilly, K., \& Martinez, L. (2007). A pilot study examining the longer term stability of the scientist-practitioner model of training. American Behavioral Scientist , 50 (6 ), 830-841. Retrieved from http://doi.org/10.1177/0002764206297580

Labaree, D. (2003). Educational researchers. Education Researcher, 32(4), 13-22. Retrieved from http://doi.org/10.3102/0013189X014001014

Lambie, G. W. G., \& Vaccaro, N. (2011). Doctoral counselor education students' levels of research selfefficacy, perceptions of the research training environment, and interest in research. Counselor Education \& Supervision, 50(June), 243-258. Retrieved from http://doi.org/10.1002/j.15566978.2011.tb00122.x

Lee, C. (1982). Self-efficacy as a predictor of performance in competitive gymnastics. Journal of Sports Psychology, 4(4), 405-409.

Lee, C. (1984). Accuracy of efficacy and outcome expectations in predicting performance in a simulated assertive task. Journal of Counseling Psychology, 8(1), 225-232. Retrieved from http://doi.org/10.1007/BF01315096

Leech, N. L. (2012). Educating knowledgeable and skilled researchers in doctoral programs in schools of education: A new model. International Journal of Doctoral Studies, 7, 19-37. Retrieved from http://ijds.org/Volume7/IJDSv7p019-037Leech325.pdf

Leech, N. L., \& Haug, C. A. (2015). Investigating graduate level research and statistics courses in schools of education. International Journal of Doctoral Studies, 10, 93-110. Retrieved from http://ijds.org/Volume10/IJDSv10p093-110Leech0658.pdf

Levine, A. (2005). Educating school leaders. The Education Schools Project, Washington, D.C.. Retrieved from http://www.edschools.org/pdf/Final313.pdf

Lincoln, Y. S., \& Guba, E. G. (1985). Naturalistic inquiry. Newbury Park, CA.: Sage Publications.

Lovitts, B. E. (2005). Being a good course-taker is not enough: A theoretical perspective on the transition to independent research. Studies in Higher Education, 30(2), 137-154. Retrieved from http://doi.org/10.1080/03075070500043093

Murakami-Ramalho, E., Militello, M., \& Piert, J. (2013). A view from within: How doctoral students in educational administration develop research knowledge and identity. Studies in Higher Education, 38(2), 1-16. http://doi.org/10.1080/03075079.2011.578738

Murakami-Ramalho, E., Piert, J., \& Militello, M. (2008). The wanderer, the chameleon, and the warrior: Experiences of doctoral students of color developing a research identity in educational administration. Qualitative Inquiry, 14, 806-834. http://doi.org/10.1177/1077800408318309

Page, R. N. (2001). Reshaping graduate preparation in educational research methods: One school's experience. Educational Researcher, 30(5), 19-25. Retrieved from http://doi.org/10.3102/0013189X030005019

Perry, J. A. (2012). To Ed.D. or not to Ed.D.? Phi Delta Kappan , 94 (1 ), 41-44. Retrieved from http://doi.org/10.1177/003172171209400108

Riehl, C., Larson, C. L., Short, P. M., \& Reitzug, U. C. (2000). Reconceptualizing research and scholarship in educational administration: Learning to know, knowing to do, doing to learn. Educational Administration Quarterly (Vol. 36). Retrieved from http://doi.org/10.1177/00131610021969047

Schunk, D. H., \& Pajares, F. (2002). The development of academic self-efficacy. In A. Wigfield \& S. Eccles (Eds.), Development of achievement motifivation (pp. 15-31). San Diego: Academic Press. 
Shulman, L. S., Golde, C. M., Bueschel, A. C., \& Garabedian, K. J. (2006). Reclaiming education's doctorates: A critique and a proposal. Educational Researcher, 35(3), 25-32. Retrieved from http://doi.org/10.3102/0013189X035003025

Taylor, A. (2007). Learning to become researching professionals: The case of the doctorate of education. International Journal of Teaching and Learning in Higher Education, 19(2), 154-166.

Townsend, B. K., \& Hall, H. (2002). Rethinking the Ed.D., or What's in a Name? Higher Education. Paper presented at the Annual Meeting of the Association for the Study of Higher Education, Sacramento, California, November 21-24, 2002.

Turner, S. A. (2010). Teaching research to teachers : A self-study of course design, student outcomes, and instructor learning. Journal of the Scholarship of Teaching and Learning, 10(2), 60-77.

Unrau, Y. A. \& Beck, A. R. (2004). Increasing research self-efficacy among students in professional academic programs. Innovative Higher Education, 28(3), 187-205. Retrieved from http://doi.org/10.1023/B:IHIE.0000015107.51904.95

Vaccaro, N. (2009). The relationship between research self-efficacy, perceptions of the research training environment and interest in research in counselor education doctoral students: An ex-post-facto, cross-sectional correlational investigation. University of Central Florida.

Wao, H.O., Singh, O., Rich, V., Hohlfeld, T. N., Buckmaster, M., Passmore, D., ... \& Jiao, Q. G. (2009). The percieved barriers towards reading emperical articles among graduate students: A mixed methods investigation. Journal of the Scholarship of Teaching and Learning, 9(3), 70-86.

Wergin, J. F. (2011). Rebooting the EdD. Harvard Educational Review, 81(1), 119-140. Retrieved from http://www.hepg.org/her/abstract/812

Zambo, R., Zambo, D., Buss, R. R., Perry, J. A., \& Williams, T. R. (2014). Seven years after the call: Students' and graduates' perceptions of the re-envisioned Ed.D. Innovative Higher Education, 39(2), 123-137. Retrieved from http://doi.org/10.1007/s10755-013-9262-3

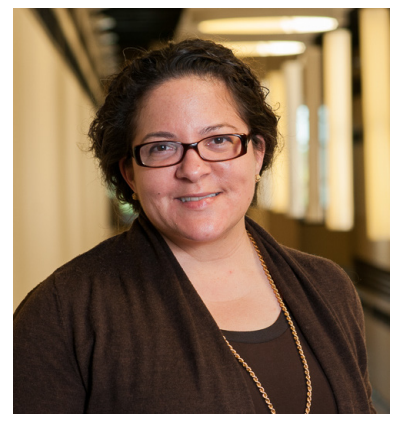

\section{Biographies}

Monica Reid Kerrigan, Ed.D. is an Associate Professor in the Educational Services and Leadership Department at Rowan University, where she coordinates the Community College Leadership Initiative track of the EdD program. Her current research focuses on methodological questions and the institutional influences on students' movement into, through, and out of college.

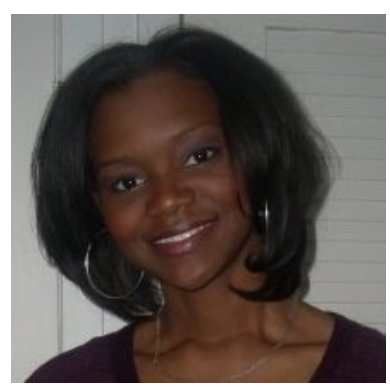

Kimberly M. Hayes, M.A. is currently the Administration Manager for Harlem Village Academies East Middle School in New York City. She completed her Masters Degree in Economics and Education at Teachers College, Columbia University in 2014 and her undergraduate studies at Howard University in 2007 . Her research interests lie mostly in equity in education and the effects of unequal education systems across states on state testing. 